\title{
Effectiveness and Forecasting of Interest Rate Reversal BI 7-Day Repo Rate in Indonesia: Lower Bound on Monetary Policy?
}

\author{
Drs. I Gede Sanica, Ak, MM ${ }^{1}$ \\ Drs. I Ketut Nurcita, $\mathrm{MM}^{2}$ \\ Drs. I Made Mastra, M.Si ${ }^{3}$ \\ Desak Made Sukarnasih, SE, MM ${ }^{4}$ \\ ${ }^{1,2,4}$ Department of Management, \\ University of Pendidikan Nasional Denpasar, Indonesia \\ ${ }^{3}$ Department of Accountancy, \\ University of Pendidikan Nasional Denpasar, Indonesia
}

Doi: $10.2478 / \mathrm{mjss}-2018-0016$

\section{Abstract}

This study aims to analyze effectivity and forecast of interest rate BI 7-Day Repo Rate as policy reference in the implementation of monetary policy. The method was used in this study contains Vector Autoregression (VAR) to estimate effectivity of BI 7-Day Repo Rate and Autoregressive Integrated Moving Average (ARIMA) to forecast of BI 7-Day Repo Rate. Period of observation in this study used time series data during 2016.4 until 2017.6. The result of this research shows that the transformation of the BI Rate to BI 7-Day Repo Rate is the right step in the monetary policy operation in the effort to reach deepening of the financial market and strengthen the interbank money market structure so that it will decrease loan interest rate and encourage credit growth. The effectiveness of the use of BI 7 Day-Repo Rate on price stability is indicated by the positive relationship between the benchmark interest rate and inflation compared to the BI Rate. The impact of BI 7-Day Repo Rate on economic growth that tends to be positive. Forecasting the use of BI 7-Day Repo Rate shows good results with declining value levels, so this will encourage deepening the financial markets.

Keywords: BI 7-Day Repo Rate, Inflation, Economic Growth, Monetary Policy

\section{Introduction}

Price stabilization is one of the main prerequisites for maintaining overall macroeconomic stability. Price stability is also a prerequisite in providing momentum for sustainable economic growth. Price control becomes very important in the economy because it determines the welfare of society not only from economic aspect but also politics, social and culture. High inflation causes society real income continues to decline so that people's living standards decline and finally promoting poverty. Unstable inflation can also create uncertainty for economic agents in making decisions. Empirical experience shows that unstable inflation will complicate people's decisions in consumption, investment, and production, which eventually will reduce economic growth. The higher domestic inflation rate compared with the inflation rate in other countries causes the real domestic interest rate become uncompetitive so it can put pressure on the rupiah exchange rate (Bank Indonesia, 2017).

Achieving price stabilization inseparable from the effectiveness of monetary policy 
implementation. Indonesia is one of the countries that adopted the inflation targeting framework since July 2005. In 1999, implicitly Indonesia implemented the inflation targeting framework as in Act No.23 of 1999 which was amended by Act No.3 of 2004. In 2003, Indonesia still implementing the International Monetary Fund (IMF) program, the operational target of monetary policy that used is base money, called inflation targeting lite country and in 2004, Bank Indonesia as central bank of Indonesia implements full-pledged inflation targeting. Implementation of the framework began in July 2005 using the $\mathrm{BI}$ rate operational target as a policy reference in signaling the achievement of the monetary policy ultimate goal. Inflation used is the Consumer Price Index (headline inflation) with time horizon is 2-5 years. Coordination with the government also has been done as arranged in inflation control roadmap since February 2005 (Bank Indonesia, 2005). BI rate is interest rate policy that reflecting the stance of established monetary policy by Bank Indonesia and announced to the public.

Transmission mechanism through the interest rate emphasizes that monetary policy will affect aggregate demand through interest rate changes that is through of short-term interest rates and transmitted at long-term interest rates. This will affect the cost of capital and ultimately impact on investment and consumption. Monetary policy operational targets are reflected in the development of Interbank Overnight (PUAB O/N) rate. The movement in this PUAB rate is expected to be followed by developments in deposit rates, and in turn bank lending rates. Taking into account the other factors in the economy, generally, Bank Indonesia will raise the BI Rate if future inflation predicted will exceed the established target, whereas Bank Indonesia will lower the BI Rate if future inflation predicted to fall below-established targets.

Effectiveness the use of interest rates in monetary policy transmission mechanism has been done through several studies in Indonesia. Warjiyo and Zulverdi (1998) studies show that monetary policy transmission through interest rates is becoming more important than transmission through the money supply and there is a close relationship between the rate of inflation and the one-month deposit rate and working capital loan. Natsir (2008) study indicates that Interbank (PUAB) rates function effectively as monetary policy operational targets in Indonesia. Alfian (2011) study shows that the role of the interest rate path in monetary policy transmission mechanism in Indonesia after the enactment of the $\mathrm{BI}$ rate in July 2005 was effective in creating credit growth over the period 2005: 07-2010: 06. Through this path, it takes a time lag about four months until the realization of credit growth in the private sector.

However, in its implementation, the use of $\mathrm{BI}$ rate as a reference rate among banks is considered ineffective in controlling the interbank (PUAB) that looks increasingly widened especially after the Fed implements Quantitative Easing (QE) policy phase II at the end of 2010 (DBS, 2017). Hence, on August 19, 2016, Bank Indonesia introduced new reference rate that is $\mathrm{BI}$ rate 7-day repo rate without changing the stance of monetary policy that applied. It aims to make interest rates policy can quickly affect the money market, banking and real sector. BI 7-Day Repo Rate instrument as a new reference has a stronger relationship to the money market rate, transactional or traded on market, and encouraging financial markets deepening. Bank Indonesia keep maintains a symmetrical and narrower interest rate corridor, that is the lower boundary of the corridor (deposit facility rate/DF rate) and the upper limit of the corridor (lending facility rate/ LF rate) respectively on 75 bps below and above BI 7-day repo rate. Strengthening the monetary operational framework is common in many central banks in the world and is an international best practice in the implementation of monetary policy in achieving price stability. The strengthening of the monetary operation framework also considers favorable macroeconomic conditions in recent times, that's giving momentum for strengthening the monetary operations framework.

Interest rates decrease or often known as interest rate reversal on the one side can encourage price stability and economic growth, but if it happens in the long term can cause credit decline and economic growth. Reversal interest rate is the interest rate level in monetary policy which can give reverse and contraction effect in giving credit. Lower interest rates will lower monetary policy compared with giving stimulus on credit and macroeconomic stability. Reversal interest rate does not have to reach zero. If interest rates to negative then will cause the vulnerability of financial stability. Because the reversal interest rate depends on macroprudential policy in financial policy. 
Responding to the use of $\mathrm{BI}$ 7-day repo rate in the implementation of monetary policy in Indonesia, this study aims to (1) analyze the effectiveness of using BI 7-day repo rate in monetary policy in Indonesia; (2) analyze to forecast of BI 7-day repo rate movement in Indonesia.

\section{Literature Review}

\subsection{Mechanism of Monetary Policy Transmission Through the Interest Rate Path}

Monetary policy implementation is focus on what instruments, operational goal, intermediate goal and final goal of the policy that used. This policy mechanism generally begins with the determination of the final goal to be achieved and then sets the intermediate goal, operational goal and the latter establishes the instruments that are actual variables that can be controlled to achieve operational goal (Walsh, 2001:386).

Intermediate goal is required to achieve the final goal in the implementation of monetary policy. Hence the need for indicators to know the indication of policy that called intermediate goal. The intermediate goal which selected should have a stability relationship with the final goal. Some intermediate goal that can be used are monetary items such as M1, M2 or credit, and interest rates. To achieve the intermediate goal, the central bank needs operational targets so that the transmission process goes according to the plan. The chosen goal should have a stability relationship with intermediate goals that controlled by the monetary authority, and information available earlier than intermediate goal. Several choices of operational goals that can be used are primary money (M0) and short-term interest rates.

The monetary instrument is an instrument owned by the central bank that can be used either directly or indirectly to influence the established operational goals. Some of the instruments that used are open market operations, reserve requirement, discount facility and moral suasion. The use of intermediate goal depends on the operational approach that used by the central bank. There are two approaches used are based on quantity-based approach and based on price-based approach.

There is four major transmission mechanism channel that shows how monetary policy can affect the economy that are the interest rate, exchange rate, asset price and credit path. Basically, the interest rate is a Keynessian view where the long-term real interest rates are most influential in the economy. The existence of monetary tightening by reducing the money supply and in the short term will cause the rise in short-term nominal interest rates. If this policy is considered credible, then people will have expectations that the inflation rate will decline in the future so inflation expectations will decline or increase in long-term real interest rates. Domestic demand for both investment and consumption will decline as the higher cost of capital. This will cause the economic growth rate tend to be lower.

In reality, the monetary policy transmission mechanism is a complex process, hence in monetary theory often called the black box. This is because the transmission mechanism is influenced by three things that is (1) changes the behavior of central banks, banks and economic agents in various economic and financial activities, (2) the length of deadline lag of monetary policy is pursued until the inflation target is reached, also occurrence change on the monetary transmission channel according to with economic and financial developments.

Monetary policy through the interest rate channel is the monetary policy for influence aggregate demand through interest rate changes. The monetary transmission mechanism through the interest rate change or price channel that emphasizes the role of interest rate changes in financial sector, by running short-term interest rate as a target (operational target) and influencing the price variables in financial markets then to the real sector and finally to the inflation rate. For achieving the final goal of controlling the rate of inflation, Bank Indonesia uses the short-term interest rate, which is the PUAB rate, as an operational target. To control the PUAB rate, the main instrument that can be used is open market operation (OMO) through selling / buying SBI (Bank Indonesia Certificate) / SBPU (money market securities) activities. The change of the SBI / SBPU interest rate will be transmitted to the PUAB rate henceforward to deposit and exchange rate. The rupiah exchange rate will be affected by PUAB rate with assumption that Indonesia preserve a 
floating exchange rate system. These two variables will then be transmitted to the real sector through their effect on the national output level. The difference between the actual output and the potential output will affect the rate of inflation (Warjiyo and Zulverdy, 1998).

\subsection{Empirical Study}

Research of Warjiyo and Zulverdy (1998) analyze the monetary transmission mechanism and the appropriate monetary policy operational framework for Indonesia within the context of changing the paradigm of monetary control. The study, which spans from 1989 to 1997 using quarterly data, uses inflation targeting by adopting a monetary policy transmission mechanism in Australia and New Zealand. The results show that (1) there is a strong enough assurance that the transmission monetary policy through interest rates becomes more important than the transmission through the money supply so the application of the monetary control system using the interest rate as the operational target is feasible to be considered; (2) there is a close relationship between the inflation rate and the interest rate (one-month time deposits and working capital loans); and (3) PUAB rate can be considered to be operational target because it has close relation with deposit rate, reflecting liquidity condition in money market, and at the same time can be affected by OMO instrument. Natsir (2008) study indicates that Interbank (PUAB) rates function effectively as operational targets for monetary policy in Indonesia. Alfian (2011) study shows that the role of the interest rate channel in the monetary policy transmission mechanism in Indonesia after the enactment of the $\mathrm{BI}$ rate in July 2005 was effective in creating credit growth over the period 2005: 07-2010: 06. Through this channel, it takes a time lag about 4 months until the realization of credit growth in the private sector.

While studies on the effectiveness of lower interest rate have been done by Claessens et al. (2017) examines the substitution between net interest margin and capital valuation at certain interest rates. Bech and Malkhozov (2016) show that low interest rates below zero will transmit through all short-term risk assets. Heider et al. (2017) finds Diff-in-Diff settings using syndicated loans where banks with large deposits will more suffer by applying low-interest rates. Borio and Gambacorta (2017) analyse the effectiveness of monetary policy on bank lending in a low-interest rate environment. Based on a sample of 108 large international banks, our empirical analysis suggests that reductions in short-term interest rates are less effective in stimulating bank lending growth when rates reach a very low level. This result holds after controlling for business and financial cycle conditions and different bank-specific characteristics such as liquidity, capitalization, funding costs, bank risk, and income diversification.

The concept of balance heet channel of monetary policy and bank lending channel, emphasizing the importance of the balance sheet structure and net worth for the transmission of monetary policy (Bernanke and Blinder, 1988; Bernanke and Gertler, 1995). The other study such as De Bondt (2005) shows that the immediate pass-through to lending and deposit rates is at most $50 \%$ at a three-month horizon. Rognlie (2016) suggest that, although there is no effective zero lower bound on deposit rates, the elasticity of demand changes at zero and sub-zero rates, which affects the pass-through.

\section{Research Methods}

\subsection{Types and Data Sources}

The type of data used in this research is time series data Indonesia monthly during 2016.4 - 2017.6. This research is specifically to analyze the use of $\mathrm{BI} 7$-day repo rate in monetary policy in Indonesia. The data source was obtained from Indonesian Financial Statistics of Bank Indonesia. Some of the variables that used in the model are inflation rate, real output, $\mathrm{BI}$ rate, $\mathrm{BI}$ 7-day repo rate, the money supply and exchange rate.

a. Inflation rate is a change in the Consumer Price Index (headline inflation).

b. Real Output is the value of Indonesia's Gross Domestic Product (GDP) at constant prices with the base year of 2010 .

c. The money supply or M2 is the sum of money in circulation (M1) consisting of currency 
outside commercial banks and Rural Bank (RBs) and Rupiah demand deposits, quasi money consists of time deposits, savings and foreign currency demand deposits and securities other than shares.

d. Interest rate reference Central Bank of Indonesia: $\mathrm{BI}$ rate and $\mathrm{BI} 7$ - day repo rate.

e. The nominal exchange rate from the middle value of domestic currency Rupiah against the US dollar.

\subsection{Data Analysis Technique}

\subsubsection{Vector Autoregression (VAR)}

This research uses Vector Autoregression (VAR) method. VAR is a system of dynamic equations that examines the relationship between economic variables by using minimal assumptions about underlying economic structures / theories. VAR explains that every variable that exists in the model depends on the past movements of the variable as well as the past movement of all the variables that present in the system. VAR less emphasized on economic assumptions, but VAR focuses on obtaining better statistical value from past interactions between economic variables and determining models based on that data. Representations of the unrestricted VAR model as follows (Harris, 1995: 77):

If $\mathrm{zt}$ is vector of $\mathrm{n}$ endogenous variables and an unrestricted VAR model with lag $\mathrm{p}$ as follows:

$$
z_{t}=A_{1} z_{t-1}+\ldots+A_{p} z_{t-p}+u_{t} \quad u_{t} \infty I N(0, \Sigma)
$$

Where, ${ }_{t}$ is vector $n x 1$ and each $A_{p}$ is the matrix parameter (nxn).

In the VAR model, there are four points to consider in establishing a system of equations, there are data descriptions, forecasts, structural inference and policy analysis. VAR is equipped with impulse response that is endogenous variable response due to innovation (shock) from other endogenous variables. By using impulse response, it can track the current and future responses of each variable due to the change or shock of a particular variable. VAR will only produce a satisfactory estimate if the entire data used is stationary. If the data is not stationary and VAR is estimated at the level without entering the cointegration restriction, then the parameters estimated in the VAR are consistent but the parameter estimation is inefficient because the information about cointegration is ignored (long-term relationship). The alternative solution is to use Vector Error Correction Model (VECM) which can generate more accurate and efficient parameter estimation.

The impulse response function can be derived from two types of VAR, that VAR with variables in level and VECM by using variable I (1) which has a cointegration relationship. Decreasing the impulse response function of VAR level and VECM requires representation of the model in shock form, with vector-moving average representation. To obtain an impulse response, a set of restriction identifiers must be entered. There are two approaches used to identify these shock. First based on the contemporaneous effect of the shock, the second is based on the long-term restriction of the impact of the shock.

Determining lag lengths is a separate issue in VAR or VECM. A long lag will reduce the degree of freedom, which implies a loss of information required and a lag that too short will result wrong model (misspecification model). Furthermore, the issue of lag length determination is also increasingly important along with assumption that appropriate lag selection will result in Gaussian residuals or no autocorrelation and heteroscedasticity (Gujarati, 2003: 853; Enders, 1995: 313; Harris, 1995: 81; Harris and Sollis, 2003).

\subsubsection{Autoregressive Integrated Moving Average (ARIMA)}

AR, MA, ARMA models require that time series data that observed has a stationary nature. Time series data is said to be stationary if it meets three criteria that is, if time series data has constant averages, variants, and covariance. If the time series data used is not stationary in level, then the data is likely to be stationary through a different process. Models with stationary data through differencing process are called ARIMA models. If, the stationary data on the differencing process $d$ 
times and apply ARMA (p, q), then the model is ARIMA ( $p, d, q)$ where $p$ is the level of AR or degree of autoregresif, $d$ the process level make the data becomes stationary or different degrees, and $q$ is the MA or moving average degree. ARIMA ( $p, d, q)$ is a combination of past values of dependent variables with past residuals and offers a better model that can't be explained well by AR or MA models only. Forecasting is the last stage of the ARIMA model. Forecasting is done to plan the future.

\section{Analysis Result}

This study aims to see the effectiveness of the use of BI 7-day repo rate in monetary policy in Indonesia. Analytical methods used are Vector Autoregression (VAR) and Autoregressive Integrated Moving Average (ARIMA) to see the BI 7-day repo rate forecasting.

\subsection{Stasionerity and Cointegration Test}

The unit root test is a data stationarity test that intended for observes whether a particular coefficient of an estimated autoregressive model has a value of one or nothing. The behavior of data from each variable can be seen in Table 1 which shows that all data moves away from the average. This indicates that all variables are not stationary at the level except $\mathrm{BI} 7$-day rate repo variable. Based on table 1 seen that using the Augmented Dickey Fuller test shows BI 7-day repo rate rate has been stationary at level $\mathrm{I}(0)$ on the degree of confidence $\alpha=5 \%$. The use of unit root test Dickey Fuller test has a disadvantage especially in the alternative hypothesis with the unit roots approaching one. According to Blough in Harris (1995), trade- off between size and power has a tendency to reject the null hypothesis when data generated process (d.g.p) approaches stationary especially for limited samples. This causes the data to be uninformative with the presence or absence of the unit root.

Table 1: Unit Root and Integration Degree Test

\begin{tabular}{|c|l|c|c|c|}
\hline No. & Variable & $\mathrm{I}(0)$ Statistic Test & $\mathrm{I}(1)$ Statistic Test & $\mathrm{I}(2)$ Statistic Test \\
\hline 1. & Inflation & $-0,749$ & $-4,397^{\star \star *}$ & $-2,911^{*}$ \\
\hline 2. & Real Output & $-0,908$ & $-0,877$ & $-3,114^{\star *}$ \\
\hline 3. & Exchange Rate & $-3,348^{* *}$ & $-2,333$ & $-6,636^{*}$ \\
\hline 4. & BI-7 Day Repo Rate & $-4,867^{*}$ & $-1,195$ & $-5,633^{*}$ \\
\hline 5. & Money Supply & $-0,150$ & $-3,632^{\star *}$ & $-3,535^{\star *}$ \\
\hline
\end{tabular}

Notes: ${ }^{* * *},{ }^{* *},{ }^{*}$ indicates significance at $\alpha=1 \%, 5 \%$ and $10 \%$

Source: Data Processed, 2017

Because not all variables have the same degree of stationarity, then the first degree of integration test is done as the following table. Similarly with first integration degree test I (1) not all variables integrate on the same degree, then the second degree integration test I (2) is done as the following below. All variables have stationary at the same degree of integration that is at integration I(2).

\subsection{Vector Autoregression (VAR)}

Impulse response analysis illustrates the effect of shock on the endogenous variables contained in the model and to see the dynamic interrelations between the variables in the model. In this case can be seen how the relation between variables is the interest rate comparing the use of $\mathrm{BI}$ Rate and BI 7-Day Repo Rate to other macroeconomic variables such as money supply, exchange rate, inflation and real output based on estimation result of VAR model.

Based on Figure 1 below, the effect of shock sourced from $\mathrm{BI}$ rates level provides a permanent effect that leads to an increase in inflation at the beginning of a period in which an increase of one standard error of the $\mathrm{BI}$ rate will cause increase of inflation at amount $0.000 \%$, vice 
versa. In the second month, inflation experienced the highest increase from the shock of $0,087 \%$ and in the third month decreased but remained positive. While the real output has a positive relationship where at the beginning of the period interest rate increase causes the output increased to $0.00026 \%$ much lower effect compared by inflation. BI Rate effect on real output tend to be permanent and positive. While the exchange rate tends to also have a positive relationship up to the second month of $0.00126 \%$, while in the third month and long term have influence or negative relationship with the highest value of $0.002 \%$. The use of the $\mathrm{BI}$ rate as the interest rate reference is less effective in exchange rate stabilization where an increase in the interest rate causes a decline in the exchange rate.

Response to Cholesky One S.D. Innovations \pm 2 S.E.

Response of INFLASI to BI_RATE

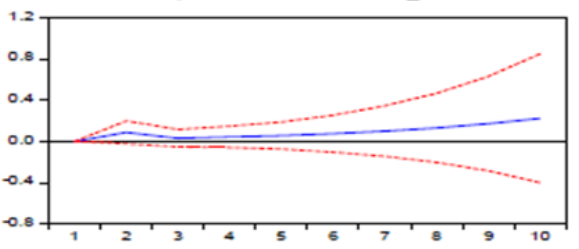

Response or LKURS to BI_RATE

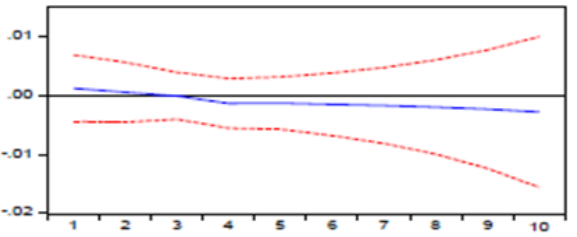

Response of LPDB to BI_RATE

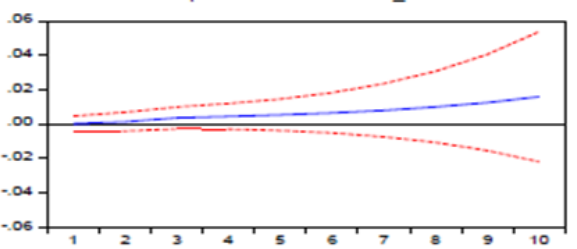

Response of INFLASI to LMR

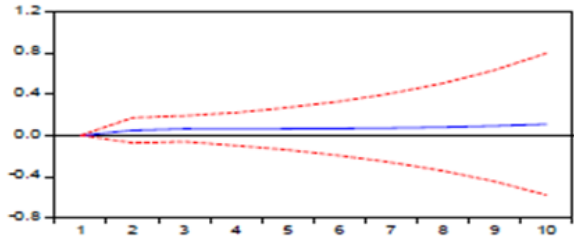

Response of LKURS to LM2

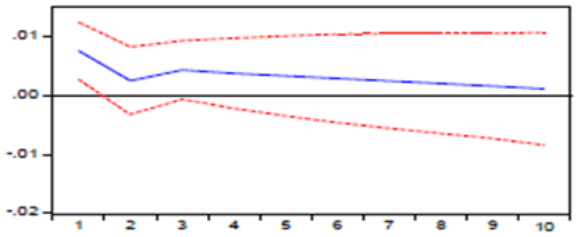

Response of LPDB to LM2

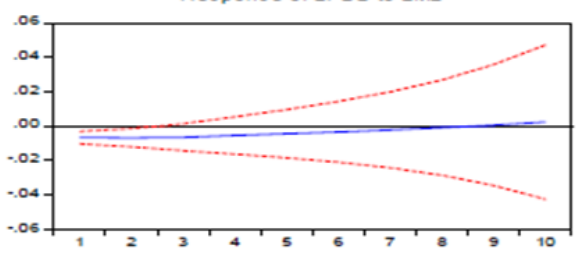

Figure 1: Impulse Response of BI Rate and Money Supply to Inflation, Output, and Exchange Rate Source: Data Processed, 2017

The shocks that come from money supply cause a positive influence on inflation of $0.000 \%$ at the beginning of the period and has a positive and permanent effect over the long term. The effect of money supply on the exchange rate tends to be positive, where at the beginning of the period of increase of one standard error of money supply will cause an exchange rate increase of $0.0076 \%$ and decrease to $0.0012 \%$ on the tenth horizon. The indirect mechanism of base money influence occurs through an increase in interest rates, but this occurs only in the short term. While against real output tends to have negative relationship and go to balance.

Meanwhile, when using $\mathrm{BI}$ 7-day repo rate instrument, based on figure 2, the effect of shock from BI 7-Day Repo Rate gives effect or positive relationship at the beginning of period where there is a standard error increase from BI 7-day repo rate causes an inflation increase of $0.000 \%$, vice versa. This is due to the adjustment of the transfer of the use of the interest rate reference in monetary policy from the previous using $\mathrm{BI}$ Rate. However in the second period, there was a negative relationship where a one standard error increase of the BI 7-day repo rate would cause a $0.0191 \%$ reduction in inflation. But in the eighth period showed a positive relationship with the shock reached $0,006 \%$ from the $\mathrm{BI}$ 7-day repo rate increase which led to an increase in inflation, vice versa. While against the level 
of output causes a positive influence, at the beginning of the period reached $0.0024 \%$ is much lower effect than on inflation. The effect of $\mathrm{BI} 7$-days repo rate on real output tends to balance and positive until the highest reaches $0.0051 \%$. While the exchange rate tended to have a positive influence at the beginning of the period that is equal to $0.0069 \%$, while in the second period showed a negative relationship with the shock of $0,003 \%$ and to the balance

Response to Cholesky One S.D. Innovations \pm 2 S.E.

Response of INFLASI to BI_RR

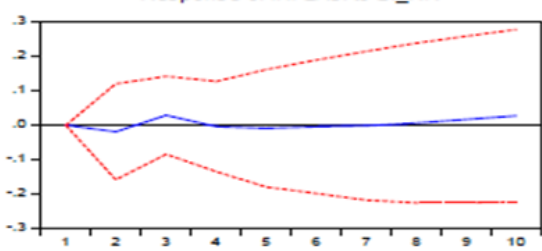

Response of LKURS to BI_RR

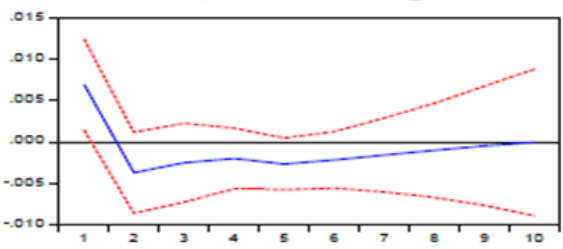

Res ponse of LPDB to BI_RR

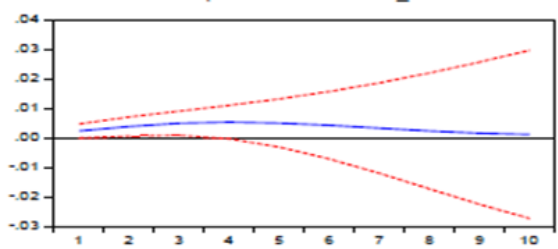

Response of INFLASI to LM2

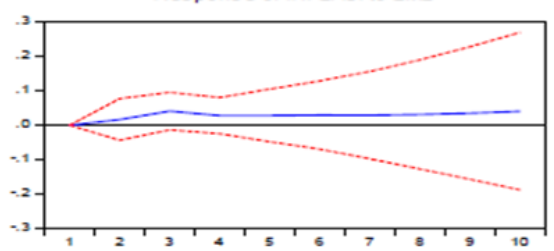

Response of LKURS to LMV

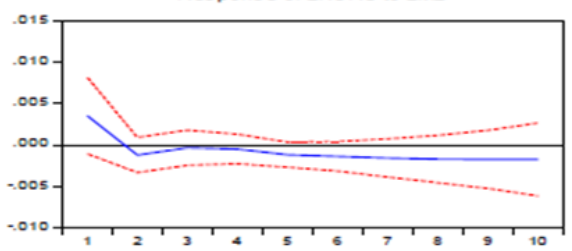

Response of LPDB to LM2

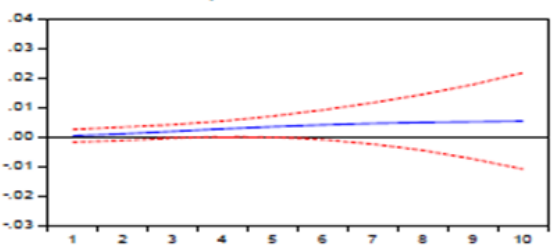

Figure 2: Impulse Response of BI 7-Day Repo Rate and Money Supply to Inflation, Output, and Exchange Rate

Source: Data Processed, 2017

While the shocks that come from money supply cause a positive influence on inflation of $0.000 \%$ at the beginning of the period and has a positive and permanent effect over the long term. The effect of money supply on the exchange rate tends to have a negative relationship, only at the beginning of the period has a positive relationship where an increase of one standard error of money supply will cause an exchange rate increase of $0.0035 \%$ and has a negative and permanent relationship. While the output has a positive and permanent relationship.

\subsection{Autoregressive Integrated Moving Average (ARIMA)}

The effectiveness of using BI 7-day repo rate in transmission mechanism monetary policy in Indonesia is crucial in achieving the ultimate policy objectives of price stability and economic growth. Forecasting the effectiveness of BI 7-day repo rate becomes an important part by using ARIMA model.

Based on the stationary test results, all variables are stationary in integration degree I (2) and autoregressive correlogram Autoreggressive $A R(2)$ and Moving Average MA(2). So the ARIMA model used is ARIMA $(2,2,2)$. Thus, using the ARIMA model $(2,2,2)$, the BI 7 -day repo rate test with the value of Theil inequality coefficient, bias proportion and small variance proportion at least less than 0.2 with the value of covariance proportion close to 1, (Root Mean Squares Error /RMSE) at least shows good in-sample forecasting which tends to decrease up to 0.087 percent. 


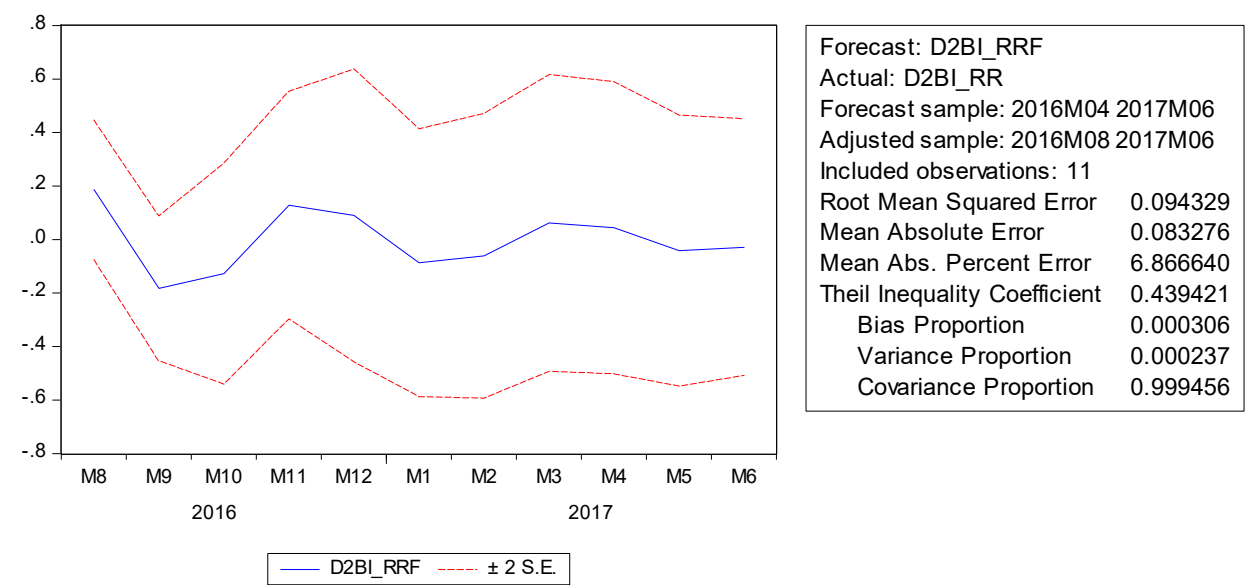

Figure 3: Forecasting Result of Interest Rate Reference BI 7-Day Repo Rate Source: Data Processed, 2017

Based on the forecasting results against interest rate reference moving of $\mathrm{Bl}-7$ day repo rate, the value of deviation decreased to 0.028 . This indicates a positive indication, especially in encouraging the deepening of the financial sector, but lower interest rates in the long run cause net interest margin to be negative and lower credit. Some transmission mechanisms of how the decline in interest rates affect bank profits, equity and credit are as follows (Brunnermeier and Koby, 2017).

1. Banks with long-term fixed-rate assets enjoy a benefit from the low interest rates whereby banks may refinance long-term assets at a cheaper rate. Increase in the value of equity and capitalization As Brunnermeiier and Sannikov (2012) with "I Theory of Money" that lower interest rates encourage stealth recapitalization of banks.

2. Low interest rates lead to bank profits in new businesses through low net interest margin where in the case of the perfect competition financial sectors, the looseness of monetary policy leads to savings and credit and at the same time promotes economic growth. But in reality financial markets are not in perfect competition and banks have market power. Banking has market power in the ability to channel credit and increase savings. So when banks have to lower interest rates, the results of assets and reserves decline. This causes marginal benefit from the increase of deposits also decreased. Decrease in deposits followed by marginal benefit from credit. While the decline in assets causes banks to lower the credit at risk as substitution of safe asset position on higher yields.

3. Changes in profits that are affected by declining interest rates provide feedback on credit. If capital gains are too low to cover losses in net interest margin then net worth also decreases at the point where the limit of constraints is on the bank's limitations to risk.

\section{Conclusion}

Implementation of monetary policy in achieving the ultimate goal ie price stability and provide momentum for the achievement of economic growth is determined by the effectiveness of the use of short-term instruments in a monetary policy transmission mechanism. By providing a conducive momentum for economic growth, it is expected to create an overall stabilization of the economy.

1. The transformation of the use of interest rate reference from BI Rate to BI 7-Day Repo Rate is the right step in monetary policy operation in the effort to reach the deepening of the financial market and strengthen the interbank money market structure so that it will lower the loan interest rate and encourage credit growth.

2. The effectiveness of the use of BI 7 Day-Repo Rate on price stability is indicated by a positive relationship between the interest rate reference and inflation having a lower 
deviation compared to the previous interest rate reference BI Rate.

3. Forecasting the use of BI 7-Day Repo Rate shows declining value, so this will encourage deepening financial market.

4. Decrease in BI-7 Day Repo Rate on one hand has positive implications for price stability and economic growth, but on the other hand prudent principles in liquidity management and credit growth are very important especially in facing the challenge of global financial dynamics vulnerability and economic actors moral hazard against risk taking in credit so not cause the paradox of credibility.

5. The approach of risk taking channel also becomes very important in monetary policy transmission mechanism.

\section{References}

Alfian, M. (2011). Efektivitas Mekanisme Transmisi Kebijakan Moneter Pada Jalur Suku Bunga Periode 2005:07-2010:06. Media Ekonomi, Vol.19 No.2, Agustus.

Bank Indonesia. (2003). Bank Indonesia: Bank Sentral Republik Indonesia, Tinjauan Kelembagaan, Kebijakan, variab Organisasi. Pusat Pendidikan dan Studi Kebanksentralan, Jakarta: Bank Indonesia.

Bank Indonesia. (2017). Laporan Perekonomian Indonesia. [Online] Available: http://www.bi.go.id/id/publikasi/laporan-tahunan/perekonomian/Default.aspx (September, 29, 2017).

Bech, M. and Malkhozov, A. (2016). How Have Central Banks Implemented Negative Policy Rates?. BIS Quarterly Review, 31-44.

Bernanke, B.S. and Blinder, A.S. (1988), Credit, Money, and Aggregate Demand. The American Economic Review, Vol. 78, No. 2.

Bernanke, B.S. and Gertler, M. (1995), Inside the Black Box: The Credit Channel of Monetary Policy. The Journal of Economic Perspectives, Vol.9, No.4.

Borio, C. and Gambacorta, L. (2017). Monetary Policy and Bank Lending in A Low Interest Rate Environment: Diminishing Effectiveness?. BIS Working Papers, 612, February.

Brunnermeier, M.K. and Koby, Y. (2017). The "Reversal Interest Rate": An Effective Lower Bound on Monetary Policy. [Online] Available: https://scholar.princeton.edu/sites/default/files/markus/files/16f_reversalrate.pdf (September, 29, 2017).

Brunnermeier, M.K. and Sannikov, Y. (2016). Thevl Theory of Money. NBER Working Paper Series, 22533, August.

Claessens, S., Coleman, N., and Donnelly, M. (2016). "Low-for-long" interest rates and net interest margins of banks in Advanced Foreign Economies. [Online] Available: https://www.federalreserve.gov /econresdata/notes/ifdp-notes/2016/low-for-long-interest-rates-and-net-interest-margins-of-banks-inadvanced-foreign-economies-20160411.html (September, 25, 2017).

DBS. (2017). Menguji Efektivitas Kebijakan Suku Bunga Baru. DBS Asian Insights. [Online] Available: https://www.dbsinsights.com/id/pertumbuhan-asia/menguji-efektivitas-kebijakan-suku-bunga-baru (September, 29, 2017).

De Bondt, G. J. (2005). Interest Rate Pass-Through: Empirical Results for The Euro Area. German Economic Review, 6 (1), 37-78.

Enders, W. (1995). Applied Econometric Time Series. New York: Jhon Wiley \& Sons.

Gujarati, D.N. (2003). Basic Econometrics. the $4^{\text {th }}$ eds. New York: McGraw Hill, pp.275-276.

Harris, R. and Sollis, R.. (2003). Applied Time Series Modelling and Forecasting. England: John Willey \& Sons Ltd.

Harris, R. (1995). Cointegration Analysis in Econometric Modelling. Harvester Wheatsheaf: Prentice Hall.

Heider, F., Saidi,F., and Schepens, G. (2017). Life Below Zero: Bank Lending Under Negative Policy Rates. [Online] Available: https://www.finance.dauphine.fr/wp.../2017/04/Florian-Heider.pdf (September, 25, 2017).

Natsir, M. (2008). Peranan Jalur Suku Bunga Dalam Mekanisme Transmisi Kebijakan Moneter Di Indonesia. [Online] Available: http:// jurnal.unhalu.ac.id/download/ Pera $n$ a $n$ - Ja lur-S u ku - B u $n$ ga dalamMekanisme-Transmisi-K e b i j a k a n - M o n e t e r - d i -Indonesia.pdf (September, 25, 2017).

Rognlie, M. (2016). What Lower Bound? Monetary Policy with Negative Interest Rate. Working Paper. [Online] Available: mattrognlie.com/negative_rates.pdf. (September, 25, 2017).

Walsh, C.E. (2001). Monetary Policy and Theory. The MIT Press

Warjiyo, P. and Zulverdy, D. (1998). Penggunaan Suku Bunga Sebagai Sasaran Operasional Kebijakan Moneter di Indonesia. Buletin Ekonomi Moneter dan Perbankan, Juli. 